\title{
ANALISIS DAMPAK OTONOMI DAERAH TERHADAP STRATEGI PENGEMBANGAN PERGURUAN TINGGI SWASTA (PTS) DI KABUPATEN SLEMAN
}

\author{
Rudy Badrudin \\ Sekolah Tinggi Ilmu Ekonomi YKPN Yogyakarta \\ E mail: rudy@stieykpn.ac.id
}

\begin{abstract}
This research analyze the effect of regional autonomy to the interest of college's student candidate to continue studying in Sleman Regency which research's samples for major program's chosen was Accounting, Management, and Economics in UII, UAJY, UPNVY, and STIE YKPN. The result of research with Boston Consulting Group (BCG) Matrix shows that each major program in four universities and college was in different quadrant. Therefore, each university and college has to choose different development strategic specifically even for each major programs in each university and college, so that the major programs in four universities and college in Sleman Regency could grow and rise.
\end{abstract}

Keywords: development strategy, BCG matrix

\section{PENDAHULUAN}

Prospek pendidikan tinggi di Kabupaten Sleman didasarkan perkembangan pendidikan tinggi di Propinsi Daerah Istimewa Yogyakarta yang terjadi sesudah tahun 2001 karena pada kurun waktu tersebut telah terjadi beberapa peristiwa nasional maupun regional yang berdampak terhadap perkembangan dunia pendidikan. Beberapa peristiwa tersebut di antaranya, krisis ekonomi tahun 1998, diberlakukannya Undang-Undang tentang Otonomi Daerah pada tahun 2001, diberlakukannya Undang-Undang Sistem Pendidikan Nasional pada tahun 2003, dan isu-isu negatif misalnya tentang narkoba dan mahasiswa/pelajar dan sex bebas di kalangan mahasiswa di Yogyakarta dan Sleman. Di antara beberapa peristiwa tersebut, diduga pemberlakuan Undang-Undang Otonomi
Daerah per 1 Januari 2001 menjadi faktorfaktor penyebab turunnya minat orang tua untuk menyekolahkan anak-anaknya kuliah di Yogyakarta dan Sleman.

Krisis ekonomi yang terjadi pada tahun 1998 telah berdampak pada peningkatan jumlah pengangguran sehingga menjadi faktor negatif bagi orang tua dalam kemampuannya membiayai biaya pendidikan tinggi bagi anak-anaknya. Oleh karena itu, orang tua akan berpikir realistis dalam arti akan lebih memprioritaskan sumber keuangannya untuk membiayai kehidupan sehari-hari. Di samping itu, krisis ekonomi tersebut juga menurunkan kemampuan daya serap perusahaan dalam merekrut karyawan sehingga orang tua juga akan berpikir realistis untuk menyekolahkan anak-anaknya kuliah kalau setelah lulus dari perguruan tinggi hanya 
menjadi penganggur. Diberlakukannya Undang-Undang tentang Otonomi Daerah pada tahun 2001 yang lalu mengakibatkan beberapa daerah berlomba-lomba untuk mendirikan perguruan tinggi. Di samping itu, undangundang tersebut juga memunculkan pandangan sempit tentang fanatisme daerah yaitu pemerintah daerah hanya menerima calon pegawainya yang lulus dari perguruan tinggi di wilayah tersebut. Kedua hal ini tentunya akan berdampak negatif bagi perguruan tinggi di Kabupaten Sleman dalam penerimaan mahasiswa baru.

Keterbatasan pemerintah pusat dalam membiayai Anggaran Pendapatan dan Belanja Negara (APBN) sektor pendidikan khususnya pendidikan tinggi mengakibatkan beberapa perguruan tinggi negeri di antaranya Universitas Gadjah Mada (UGM) berubah statusnya menjadi badan hukum milik negara (BHMN). Status UGM menjadi BHMN yang dimulai pada tahun 2003 mengakibatkan UGM memiliki otoritas yang lebih besar dalam format penerimaan mahasiswa baru, penyusunan dan penetapkan kurikulum, serta menjadi lebih mandiri dalam menetapkan kebijakan pembiayaan pendidikan. Berdasarkan otoritas yang dimiliki UGM diharapkan UGM lebih mampu dalam memperoleh input calon mahasiswa baru (kualitas dan kuantitas) dan lebih fleksibel dalam menggali berbagai potensi sumber dana untuk pembiayaan operasional dan pengembangan UGM.

Pembiayaan APBN sektor pendidikan khususnya pendidikan tinggi membutuhkan anggaran pendidikan yang cukup besar. Berdasarkan perhitungan Dirjen Dikti, ratarata biaya pendidikan seorang mahasiswa S-1 mencapai Rp9.000.000 per tahun. Rata-rata biaya pendidikan per tahun yang cukup besar tersebut tidak mungkin ditanggung oleh pemerintah sendiri, artinya bagi perguruan tinggi negeri seperti UGM yang memiliki 2.300 dosen yang terdiri dari 28 persen doktor, 52 persen master, dan 20 persen sarjana dari 18 fakultas dengan 71 program studi perlu mengundang partisipasi orang tua mahasiswa dan masyarakat dalam membiayai biaya pendidikan tersebut.

Otoritas UGM yang semakin besar dalam menyusun dan menetapkan kurikulum, serta menjadi lebih mandiri dalam menetapkan kebijakan pembiayaan pendidikan mengakibatkan biaya pendidikan di UGM menjadi terkesan mahal. Sebagai gambaran, seorang mahasiswa S-1 UGM non-eksakta mengeluarkan biaya pendidikan sekitar Rp8.500.000 per tahun sedangkan seorang mahasiswa S-1 UGM eksakta mengeluarkan biaya pendidikan sekitar Rp9.900.000 per tahun. Untuk mahasiswa S-1 UGM Fakultas Kedokteran mengeluarkan biaya pendidikan Rp12.100.000 per tahun. Biaya pendidikan itu di luar SPMA (dibayar sekali selama menjadi mahasiswa) yang bervariatif per program studi per fakultas. Misalnya, SPMA Fakultas Biologi bervariasi antara Rp1.000.000 (alternatif 1), Rp2.000.000 (alternatif 2), Rp4.000.000 (alternatif 3), dan Rp6.000.000 (alternatif 4). Fakultas Ekonomi dan Kedokteran merupakan dua fakultas yang mematok SPMA paling mahal, dari termurah Rp10.000.000 sampai dengan termahal Rp50.000.000. Sebagai pembanding, seorang mahasiswa baru PTS ternama di Kabupaten Sleman pada tahun 2003, membayar biaya pendidikan SPP Tetap Rp1.000.000 per semester, SPP Variabel Rp40.000 per sks, dan Sumbangan Pengembangan Akademik (SPA) minimum Rp8.000.000. 
Otoritas yang dimiliki UGM dalam penerimaan mahasiswa baru mulai diterapkan pada tahun 2003, yaitu dengan mengadakan perubahan format ujian masuk. Format ujian masuk tahun sebelumnya adalah calon mahasiswa baru yang melalui jalur tes harus mengikuti ujian seleksi penerimaan mahasiswa baru (SPMB) yang diselenggarakan bersama dengan perguruan tinggi negeri lain secara nasional, sedangkan calon mahasiswa baru yang melalui jalur penjaringan bibit berprestasi dan penjaringan dengan sistem kemitraan (Sistem Penjaringan atau SP) harus mengikuti seleksi yang diselenggarakan tersendiri oleh fakultas di lingkungan UGM. Semua seleksi tersebut (SPMB dan SP) diselenggarakan setelah waktu pengumuman kelulusan SMU, sedangkan pengumuman hasil seleksi SPMB dan SP perguruan tinggi negeri (UGM) dilaksanakan pada akhir bulan Juli atau awal bulan Agustus. Seluruh mahasiswa baru yang diterima di UGM, baik melalui jalur SPMB maupun SP harus membayar Sumbangan Pembinaan Pendidikan (SPP) sebesar Rp500.000 per semester dan Biaya Operasional Pendidikan (BOP) sebesar Rp500.00 untuk mahasiswa fakultas non-eksakta dan sebesar Rp750.000 untuk mahasiswa fakultas eksakta.

Format ujian masuk mulai tahun 2003 adalah calon mahasiswa baru yang melalui jalur tes harus mengikuti ujian masuk UGM yang pelaksanaannya dilakukan oleh UGM sendiri (disebut Ujian Masuk UGM atau UM UGM) dan bersama dengan perguruan tinggi negeri lain secara nasional (disebut SPMB). Seleksi melalui jalur UM UGM menerima 75 persen dari rencana 6.000 mahasiswa baru (4.000 mahasiswa baru melalui jalur UM UGM dan 500 mahasiswa melalui jalur SP), sedangkan seleksi melalui jalur SPMB mene- rima 25 persen dari rencana 6.000 mahasiswa baru (1.500 mahasiswa baru). Seleksi penerimaan mahasiswa baru melalui UM UGM diselenggarakan sebelum waktu pengumuman kelulusan SMU (diselenggarakan di 17 kota di Indonesia pada tanggal 22 dan 23 April 2003). Pengumuman hasil seleksi ujian masuk melalui jalur UM UGM akan dilakukan pada akhir Mei 2003. Bagi calon mahasiswa baru yang tidak diterima melalui jalur UM UGM masih diberi kesempatan untuk mengikuti seleksi melalui jalur SPMB yang akan diselenggarakan pada bulan Juni 2003. Pengumuman hasil seleksi ujian masuk melalui jalur SPMB (UGM) dilakukan pada akhir bulan Juli atau awal bulan Agustus. Seluruh mahasiswa baru yang diterima di UGM melalui seleksi UM UGM dan SPMB harus membayar Sumbangan Pembinaan Pendidikan (SPP) sebesar Rp500.000 per semester dan Biaya Operasional Pendidikan (BOP) sebesar Rp500.00 untuk mahasiswa fakultas noneksakta dan sebesar Rp750.000 untuk mahasiswa fakultas eksakta. Di samping membayar SPP dan BOP, mahasiswa baru juga harus membayar Sumbangan Pengembangan Mutu Akademik (SPMA) minimum sebesar Rp5.000.000 (bagi yang mampu) dan bebas terbatas (bagi yang memenuhi persyaratan akademis tetapi tidak mampu secara ekonomi).

Khusus bagi calon mahasiswa baru yang diterima melalui jalur Program Swadaya, biaya pendidikan yang harus dibayarkan meliputi SPP sebesar Rp1.500.000 per semester, BOP sebesar 50.000 per sks, dan SPMA yang bervariatif terganting jenis program studi dan fakultas yang dipilih (minimum Rp5.000.000). Model pembiayaan 
pendidikan di UGM untuk mahasiswa baru tahun 2003 ditunjukkan pada Tabel 1.

Secara keseluruhan, ada 5 perguruan tinggi negeri yang berdomisili di Kabupaten Sleman, yaitu Universitas Gadjah Mada (UGM), Universitas Negeri Yogyakarta (UNY), Universitas Islam Negeri (UIN) Sunan Kalijaga, Akademi Angkatan Udara
(AAU) Adisucipto, dan Sekolah Tinggi Pertanahan Negara (STPN). Data jumlah mahasiswa baru yang mendaftar, diterima, dan jumlah keseluruhan di 5 perguruan tinggi negeri tersebut pada tahun 2002 ditunjukkan pada Tabel 2.

Prediksi pendidikan tinggi perguruan tinggi swasta untuk jumlah mahasiswa

Tabel 1. Biaya Pendidikan untuk Mahasiswa Baru UGM Tahun 2003

\begin{tabular}{|c|c|c|c|c|c|c|}
\hline Nomor & Keterangan & Program Reguler & \multicolumn{4}{|c|}{ Program Swadaya } \\
\hline 1 & SPP & Rp500.000/semester & \multicolumn{4}{|c|}{ Rp1.500.000/semester } \\
\hline 2 & BOP & $\begin{array}{l}\text { Rp500.000/semester (non-eksakta) } \\
\text { Rp750.000/semester (eksakta) }\end{array}$ & \multicolumn{4}{|c|}{$\begin{array}{l}\text { Rp50.000/sks (khusus bagi program studi Teknik } \\
\text { Pertanian Rp100.000/sks) }\end{array}$} \\
\hline \multirow[t]{2}{*}{3} & SPMA & $\begin{array}{l}\text { 1. Rp1.000.000 s.d. Rp4.000.000 } \\
\text { (Bebas terbatas bagi calon } \\
\text { mahasiswa yang memenuhi }\end{array}$ & No. & Program Studi & Fakultas & $\begin{array}{c}\text { SPMA } \\
\text { minimum } \\
(\mathrm{Rp} 000.000)\end{array}$ \\
\hline & & $\begin{array}{l}\text { 2. Minimum Rp5.000.000 (bagi yang } \\
\text { mampu) }\end{array}$ & $\begin{array}{l}1 \\
2 \\
3 \\
4 \\
5 \\
6 \\
\end{array}$ & $\begin{array}{l}\text { IImu Filsafat } \\
\text { Ilmu Hukum } \\
\text { IImu Komputer } \\
\text { Kimia } \\
\text { Psikologi } \\
\text { Program Lain }\end{array}$ & $\begin{array}{l}\text { Filsafat } \\
\text { Hukum } \\
\text { MIPA } \\
\text { MIPA } \\
\text { Psikologi } \\
\text { Studinya } \\
\end{array}$ & $\begin{array}{c}5 \\
5 \\
8 \\
6 \\
5 \\
10 \\
\end{array}$ \\
\hline 4 & $\begin{array}{l}\text { Pola } \\
\text { Seleksi }\end{array}$ & $\begin{array}{l}\text { 1. Penjaringan Bibit Berprestasi } \\
\text { 2. Penjaringan Sistem Kemitraan } \\
\text { 3. Seleksi Tulis (UM UGM dan } \\
\text { SPMB) }\end{array}$ & \multicolumn{4}{|c|}{$\begin{array}{l}\text { Seleksi Tulis yang waktunya tergantung fakultas } \\
\text { penyelenggara program swadaya. }\end{array}$} \\
\hline
\end{tabular}

Sumber: http://web.ugm.ac.id/um-ugm/um-ugm-php.

Tabel 2. Jumlah Mahasiswa Baru yang Mendaftar, Diterima, dan Jumlah Mahasiswa Total di Perguruan Tinggi Negeri, Tahun 2002

\begin{tabular}{llrrr}
\hline \multirow{2}{*}{ Nomor } & \multirow{2}{*}{ PTS } & \multicolumn{3}{c}{2002} \\
\cline { 3 - 5 } & & Pendaftar & Diterima & Jumlah Total \\
\hline 1 & UGM & 193.496 & 8.098 & 50.172 \\
2 & UNY & - & 4.697 & 10.453 \\
3 & UIN SUKA & 2.930 & 2.190 & 10.650 \\
4 & AAU ADISUCIPTO & 1.763 & 162 & 452 \\
5 & STPN & 926 & 301 & 717 \\
\hline & Jumlah & 199.115 & 15.448 & $\mathbf{7 2 . 4 4 4}$ \\
\hline
\end{tabular}

Sumber: Sleman dalam Angka Tahun 2002, BPS Kabupaten Sleman 
pendaftar, mahasiswa baru yang diterima, dan mahasiswa total mempunyai kecenderungan menurun pada tahun 2005-2009. Beberapa faktor sebagai penyebab turunnya mahasiswa pendaftar, mahasiswa baru yang diterima, dan mahasiswa total adalah mahalnya biaya pendidikan dan isu narkoba yang terjadi di Yogyakarta dan Sleman. Mahalnya biaya pendidikan di perguruan tinggi negeri maupun swasta dirasakan di berbagai kota di Indonesia, termasuk Yogyakarta dan Sleman. Beberapa tahun yang lalu, Yogyakarta dan Sleman dikenal sebagai Kota Pendidikan dengan biaya hidup yang relatif murah dibandingkan dengan kota-kota lainnya. Tetapi sebutan itu tidak berlaku lagi sekarang. Hal ini dibuktikan dengan hasil survei terhadap 875 orang yang dilakukan oleh Litbang Kompas pada tahun 2003 diperoleh hasil sebagai berikut (Tabel 3)

\section{Tabel 3. Survei Biaya Pendidikan di Perguruan} Tinggi di Berbagai Kota, Tahun 2003

\begin{tabular}{lccc}
\hline $\begin{array}{c}\text { Kota } \\
\text { Responden }\end{array}$ & $\begin{array}{c}\text { Murah } \\
\text { (\%) }\end{array}$ & $\begin{array}{c}\text { Sedang } \\
\text { (\%) }\end{array}$ & $\begin{array}{c}\text { Mahal } \\
\text { (\%) }\end{array}$ \\
\hline Jakarta & 6,9 & 22,1 & 71,0 \\
Yogyakarta & 0,0 & 5,1 & 94,9 \\
(Sleman) & & & \\
Surabaya & 6,9 & 24,4 & 68,8 \\
Medan & 11,4 & 24,3 & 64,3 \\
Padang & 38,5 & 23,1 & 38,5 \\
Banjarmasin & 15,0 & 45,0 & 40,0 \\
Pontianak & 13,6 & 45,5 & 40,9 \\
Manado & 12,5 & 8,3 & 79,2 \\
Makassar & 7,0 & 20,9 & 72,1 \\
Jayapura & 30,4 & 8,7 & 60,9 \\
\hline
\end{tabular}

Sumber: Kompas, 22 Juni 2003, hal. 32.

Berdasarkan Tabel 3, nampak tidak ada responden yang mengatakan bahwa biaya pendidikan di perguruan tinggi di kota Yogyakarta dan Sleman murah dan nampak seba- nyak 94,9 persen responden mengatakan bahwa biaya pendidikan di perguruan tinggi di kota Yogyakarta dan Sleman mahal. Mahalnya biaya pendidikan di perguruan tinggi di Yogyakarta dan Sleman akan berdampak terhadap turunnya daya saing kota Yogyakarta dan Sleman dalam kompetisi penerimaan mahasiswa baru.

Mahalnya biaya pendidikan di Yogyakarta dan Sleman dibuktikan pula dengan hasil penelitian yang dilakukan oleh Bank Indonesia (BI) Yogyakarta, yaitu selama tahun 2000-2002 biaya hidup mahasiswa di Yogyakarta rata-rata naik 8,78 persen per tahun dan di tahun 2003 diperkirakan naik 9,12 persen sehingga biaya hidup mahasiswa tahun 2002 yang sebanyak Rp8,83 juta per tahun menjadi Rp9,63 juta per tahun pada tahun 2003 atau sebanyak Rp802.549 per bulan. Komponen terbesar yang mengakibatkan kenaikan biaya hidup mahasiswa pada tahun 2003 adalah kenaikan biaya pendidikan sebanyak 11,11 persen dan kenaikan biaya kos sebanyak 8,11 persen (Kompas, 12 April 2004, hal. A). Turunnya jumlah penerimaan mahasiswa baru yang berdampak terhadap jumlah mahasiswa total pada akhirnya akan berdampak terhadap roda perekonomian Propinsi DIY. Hal ini dibuktikan dengan hasil survei BI pada triwulan II tahun 2003 yang menunjukkan bahwa banyaknya uang yang dibelanjakan oleh mahasiswa dalam 1 tahun mencapai Rp2,94 triliun atau 17,7 persen dari perputaran uang di Yogyakarta dan Sleman.

Promosi negatif (depromotion) bagi penerimaan mahasiswa baru di Yogyakarta dan Sleman, selain faktor biaya pendidikan juga isu Yogyakarta dan Sleman sebagai kota narkoba nomor 3 di Indonesia. Menurut Dinas Sosial Propinsi DIY, di DIY ada lebih 
Tabel 4. Jumlah Mahasiswa Pendaftar, Diterima, dan Total di Perguruan Tinggi Swasta Propinsi DIY, Tahun 2001-2003

\begin{tabular}{|c|c|c|c|c|c|c|c|c|c|c|}
\hline \multirow[t]{2}{*}{ Nomor } & \multirow[t]{2}{*}{ Jenis PTS } & \multicolumn{3}{|c|}{2001} & \multicolumn{3}{|c|}{2002} & \multicolumn{3}{|c|}{2003} \\
\hline & & $\begin{array}{l}\text { Pendaf- } \\
\text { tar }\end{array}$ & Diterima & $\begin{array}{c}\text { Jumlah } \\
\text { Total }\end{array}$ & $\begin{array}{l}\text { Pendaf- } \\
\text { tar }\end{array}$ & Diterima & $\begin{array}{c}\text { Jumlah } \\
\text { Total }\end{array}$ & $\begin{array}{l}\text { Pendaf- } \\
\text { tar }\end{array}$ & Diterima & $\begin{array}{c}\text { Jumlah } \\
\text { Total }\end{array}$ \\
\hline 1 & Universitas & 98,179 & 27,408 & 107,469 & 87,948 & 22,844 & 91,846 & 88,272 & 34,274 & 118,039 \\
\hline 2 & Institut & 3,146 & 2,153 & 7,530 & 2,880 & 1,879 & 4,790 & 2,671 & 2,000 & 8,715 \\
\hline 3 & Sekolah Tinggi & 17,297 & 11,866 & 38,092 & 16,263 & 8,712 & 24,242 & 16,606 & 11,151 & 39,272 \\
\hline 4 & Politeknik & 1,813 & 1,274 & 405 & 3,913 & 2,598 & 3,457 & 4,426 & 2,383 & 6,607 \\
\hline 5 & Akademi & 8,163 & 5,238 & 14,404 & 9,010 & 4,844 & 12,799 & 8,626 & 5,164 & 16,146 \\
\hline & Total & 28,598 & 47,939 & 167,900 & 120,014 & 40,877 & 137,134 & 20,601 & 54,972 & 188,779 \\
\hline
\end{tabular}

Sumber: Kopertis V Propinsi DIY. Data diolah

kurang 24.000 orang pengguna narkoba dan 50 persennya adalah pelajar dan mahasiswa. Jumlah yang cukup banyak tersebut akan semakin meningkat di tahun-tahun mendatang apabila tidak ada upaya pencegahan untuk itu. Perda DIY Nomor 3 tahun 2000 tentang Penanggulangan dan Pemberantasan Penyalahgunaan Narkotika dan Zat Aditif hanya menjadi "macan ompong" yang kurang mempunyai kekuatan dalam pencegahan penyalahgunaan narkoba. Hal ini dapat kita lihat dalam praktiknya apakah perguruan tinggi sudah melakukan seleksi terhadap mahasiswa baru berkaitan dengan tes narkoba (Kedaulatan Rakyat, 27-29 April 2004, hal. 20).

Apabila data jumlah mahasiswa pendaftar, mahasiswa baru yang diterima, dan mahasiswa total PTS di Kopertis Wilayah V Propinsi DI Yogyakarta selama tahun 20012003 dikelompokkan berdasarkan jenis pendidikan tinggi menurut universitas, institut, sekolah tinggi, politeknik, dan akademi maka akan nampak data PTS pada Tabel 4.
Berdasarkan Tabel 4, nampak jumlah pendaftar selama tahun 2001-2002 semakin menurun. Penurunan jumlah pendaftar bagi perguruan tinggi swasta akan berdampak pada pola seleksi penerimaan mahasiswa baru yang semakin tidak berkualitas apabila perguruan tinggi swasta mempertahankan jumlah mahasiswa yang diterima. Artinya rasio jumlah mahasiswa pendaftar dan yang diterima akan semakin meningkat angka persentasenya. Hal ini ditunjukkan pada Tabel 5.

Berdasarkan Tabel 5, nampak total rasio mahasiswa pendaftar dan diterima selama tahun 2001-2003 persentasenya semakin meningkat, yaitu dari 37,28 persen pada tahun 2001 menjadi 45,58 persen pada tahun 2003. Pola peningkatan rasio ini berlaku juga untuk seluruh jenis pendidikan tinggi, kecuali jenis politeknik yang rasionya semakin menurun, yaitu dari 70,27 persen pada tahun 2001, 66,39 persen pada tahun 2002, dan 53,80 persen pada tahun 2003. Hal ini menunjukkan bahwa pendidikan tinggi jenis politeknik merupakan jenis pendidikan tinggi 
Tabel 5. Rasio Jumlah Mahasiswa Pendaftar dan Diterima di Kopertis V, Tahun 2001-2003

\begin{tabular}{|c|c|c|c|c|c|c|c|c|c|c|}
\hline \multirow{2}{*}{ Nomor } & \multirow{2}{*}{$\begin{array}{l}\text { Jenis } \\
\text { PTS }\end{array}$} & \multicolumn{3}{|c|}{2001} & \multicolumn{3}{|c|}{2002} & \multicolumn{3}{|c|}{2003} \\
\hline & & Pendaftar & Diterima & Rasio & Pendaftar & Diterima & Rasio & Pendaftar & Diterima & Rasio \\
\hline 1 & Universitas & 98,179 & 27,408 & $27.92 \%$ & 87,948 & 22,844 & $25.97 \%$ & 88,272 & 34,274 & $38.83 \%$ \\
\hline 2 & Institut & 3,146 & 2,153 & $68.44 \%$ & 2,880 & 1,879 & $65.24 \%$ & 2,671 & 2,000 & $74.88 \%$ \\
\hline 3 & SekolahTinggi & 17,297 & 11,866 & $68.60 \%$ & 16,263 & 8,712 & $53.57 \%$ & 16,606 & 11,151 & $67.15 \%$ \\
\hline 4 & Politeknik & 1,813 & 1,274 & $70.27 \%$ & 3,913 & 2,598 & $66.39 \%$ & 4,426 & 2,383 & $53.8 \%$ \\
\hline 5 & Akademi & 8,163 & 5,238 & $64.17 \%$ & 9,010 & 4,844 & $53.76 \%$ & 8,626 & 5,164 & $59.87 \%$ \\
\hline & TOTAL & 128,598 & 47,939 & $37.28 \%$ & 120,014 & 40,877 & $34.06 \%$ & 120,601 & 54,972 & $45.58 \%$ \\
\hline
\end{tabular}

Sumber: Kopertis V Propinsi DIY. Data diolah berdasarkan Tabel 4.

yang paling diminati para lulusan SMA karena kurikulumnya lebih aplikatif daripada jenis pendidikan tinggi lainnya.

Penelitian ini bertujuan untuk menganalisis dampak otonomi daerah terhadap strategi pengembangan perguruan tinggi swasta (PTS) di Kabupaten Sleman. Penelitian dilakukan dengan menggunakan sampel empat PTS besar berdasarkan jumlah mahasiswa dan berlokasi yang saling berdekatan di Kecamatan Depok. Penelitian dilakukan berdasarkan perkembangan data jumlah mahasiswa baru setelah pemberlakuan otonomi daerah per 1 Januari 2001, yaitu mulai tahun 2002 sampai dengan 2007.

\section{METODE PENELITIAN}

Perguruan Tinggi Swasta (PTS) menghadapi perubahan eksternal yang sangat cepat. Perubahan eksternal tersebut mengakibatkan persaingan antarperguruan tinggi negeri dan swasta menjadi sangat ketat. PTS yang dapat memilih strategi yang tepat akan mampu memenangkan persaingan tersebut. Untuk mengantisipasi perubahan yang sangat cepat tersebut, PTS harus mampu menerapkan model manajemen dengan paradigma baru karena dengan paradigma baru, manajemen PTS dapat melakukan perbaikan dan peningkatan kualitas yang ditujukan untuk memenuhi customer satisfaction (kepuasan perusahaan perekrut lulusan PTS). Paradigma baru diperlukan untuk mengatasi perubahan yang terjadi dalam lingkungan eksternal dan bagaimana mengelola perubahan tersebut. Managerial paradigm menunjukkan cara orang berpikir dan bertindak dalam mengelola perguruan tinggi. Apabila dalam mengelola PTS, pengurus PTS menghadapi kenyataan-kenyataan yang dapat mengancam kelangsungan hidup dan prospek PTS di masa depan, maka pengurus PTS perlu untuk segera mengubah paradigmanya dengan paradigma baru (Bounds, Greg, et al., 1994, hal. 28). Pergeseran paradigma tersebut ditujukan untuk menyediakan superior customer value melalui customer value strategy, organizational systems, dan continuous improvement.

Customer value strategy adalah strategi bisnis yang berupa penawaran nilai kepada customer yang di dalamnya tidak hanya berupa produk, tetapi juga berupa karakte- 
ristik produk, pendistribusian produk, dan sebagainya (Bounds, Greg, et al., 1994, hal. 29). Customer value adalah kombinasi manfaat yang berasal dari suatu produk dan pengorbanan yang diperlukan customer dalam memenuhi kebutuhannya atau selisih antara manfaat yang diperoleh customer dari penggunaan produk dengan pengorbanan yang dilakukan customer untuk memperoleh manfaat tersebut. Salah satu pergeseran paradigma dari paradigma lama ke paradigma baru dalam customer value strategy adalah tentang topik tentang kualitas. Dalam paradigma lama, manajemen mendefinisikan kualitas dengan pencapaian yang telah ditentukan. Kualitas dijamin dengan seleksi produk sebelum dikirim ke customer. Manajemen membuat tradeoff antara kualitas, biaya, dan skedul. Dalam paradigma baru manajemen mendefinisikan bahwa kualitas produk hanya merupakan salah satu bagian dari customer value. Manajemen mencari sinergi antara kualitas, biaya, dan skedul. Untuk memiliki kemampuan bertahan, berkembang, dan memenangkan persaingan yang ketat dalam era bisnis global, organisasi bisnis harus mengarahkan semua kegiatannya untuk menghasilkan customer value.

Organizational systems adalah sarana yang menyediakan customer value. Termasuk dalam sistem ini adalah input material dan sumberdaya manusia, teknologi proses, metode operasi dan praktik kerja, aliran aktivitas kerja, aliran informasi, dan proses pengambilan keputusan. Dalam organizational systems, ada pergeseran paradigma dalam memandang cross functional approach, tehnologi, pelibatan karyawan, manajemen sumberdaya manusia,definisi peraturan, kultur, dan struktur. Misalnya, paradigma baru dalam memandang teknologi adalah teknologi digunakan untuk mengurangi kompleksitas masalah terlebih dengan menggunakan teknologi yang otomatis dan serba komputer dan manajemen menggunakan teknologi hanya untuk mengotimalkan sistem yang menghasilkan customer value. Paradigma baru dalam memandang pelibatan karyawan adalah karyawan dilibatkan dalam kegiatan PTS yang berfokus pada strategi untuk memuasi customer. Pelibatan karyawan dilakukan dengan cara memperdayakan mereka melalui continuous improvement, agar mampu memberikan kontribusi bagi PTS dan menghasilkan kepuasan customer.

Continuous improvement digunakan untuk mengelola perubahan dalam lingkungan eksternal agar PTS dapat membuat keadaan menjadi lebih baik. Improvement dalam paradigma lama dilakukan yang utama pada pengembangan produk baru dan reaksi terhadap masalah yang muncul. Improvement dalam paradigma baru dilakukan pada setiap waktu dan di manapun. Manajemen secara proaktif mengadakan perbaikan pada setiap ada kesempatan meskipun tidak ada masalah yang muncul. PTS menggunakan continuous improvement secara berkelanjutan terhadap proses dan sistem yang digunakan untuk menghasilkan customer value dengan tingkat improvement yang lebih pesat dibandingkan improvement yang dilakukan PTS pesaing.

Intensitas superior customer value melalui customer value strategy, organizational systems, dan continuous improvement ditentukan oleh keunggulan masing-masing PTS yang dapat dianalisis menggunakan matriks pertumbuhan-pangsa pasar (growthshare matrix - GS Matrix). GS Matrix atau Boston Consultant Group Matrix/BCG Matrix memiliki empat kuadran yang dipisahkan oleh dua sumbu, yaitu sumbu 
vertikal dan sumbu horisontal. Sumbu vertikal menunjukkan kontribusi PTS terhadap PTS keseluruhan di Kabupaten Sleman dan sumbu horisontal menunjukkan laju pertumbuhan PTS. Kontribusi suatu PTS diukur dari kontribusi persentase jumlah mahasiswa PTS tersebut terhadap jumlah mahasiswa PTS keseluruhan di Kabupaten Sleman. Sedangkan laju pertumbuhan PTS diukur dari persentase perubahan jumlah mahasiswa PTS tersebut dari tahun ke tahun.

Andriani, Lis HR (2001), menggunakan BCG Matrix untuk meneliti 9 (sembilan) PTS di Kota Surabaya yang mempunyai Fakultas Ekonomi Jurusan Manajemen dengan status terakreditasi B berdasarkan data Direktori Kopertis Wilayah VII, Tahun 1999. Penelitian ini bertujuan untuk menentukan posisi keunggulan kompetitif masingmasing PTS berdasarkan faktor-faktor keberhasilan kritis internal maupun eksternal yang dimilikinya, serta menentukan strategi apa yang paling sesuai untuk diterapkan berdasarkan posisi tersebut. Penelitian ini menggunakan metode analisis kualitatif, yaitu analisis BCG Matrix. Hasil penelitian menunjukkan bahwa pertama, Unika Widya Mandala, UK Petra, dan Ubaya berada pada posisi yang sangat menguntungkan yaitu terletak di kuadran 1, sementara keenam PTS lainnya berada pada kuadran 2, yang berarti memiliki posisi cukup menguntungkan. Kedua, alternatif strategi yang dapat diterapkan untuk masing-masing PTS adalah sebagai berikut: Unika Widya Mandala sebaiknya melakukan strategi pengembangan pasar; Untag, UPB, UPN "Veteran" Surabaya, dan Ubhara dianjurkan untuk menerapkan strategi pengembangan produk; Unitomo dengan strategi integrasi ke belakang; Unipra menggunakan strategi penetrasi pasar; dan
UK Petra dan Ubaya sebaiknya melaksanakan strategi integrasi horizontal. Strategi tersebut dapat dijadikan acuan penyusunan strategi jangka panjang dalam rangka pengembangan masing-masing PTS, sehingga diharapkan pengembangannya akan semakin terarah, terfokus, efektif, dan efisien dalam mencapai visi dan misi organisasi.

Algifari dan Rudy Badrudin (2003: 203213), melakukan penelitian untuk menguraikan strategi yang dapat digunakan pemerintah daerah dalam memanfaatkan keterbatasan sumberdaya untuk memperoleh hasil pembangunan yang optimal. Strategi tersebut berkaitan dengan pengidentifikasian karakteristik lokasi (dalam hal ini kecamatan), kemudian memasukkan kecamatan tersebut ke dalam suatu kelompok tertentu. Tujuannya adalah untuk menentukan strategi pembangunan yang cocok bagi masing-masing kelompok kecamatan. Pengelompokan kecamatan dilakukan dengan menggunakan model Growth-Share BCG Matrix. Setiap kecamatan diidentifikasi pertumbuhan ekonomi (growth) dan kontribusi (share) PDRB kecamatan terhadap PDRB kabupaten. Hasil identifikasi menunjukkan bahwa tidak satu pun kecamatan di Kabupaten Sleman yang memiliki pertumbuhan tinggi dan kontribusi tinggi. Kecamatan Cangkringan, Ngemplak, Pakem, Prambanan, dan Turi memiliki kontribusi yang tinggi bagi PDRB kabupaten, namun pertumbuhan ekonominya rendah. Kecamatan Depok, Gamping, Malti, Ngaglik, dan Sleman memiliki pertumbuhan ekonomi tinggi, namun kontribusi bagi PDRB kabupaten rendah. Sedangkan kecamatan Berbah, Godean, Kalasan, Minggi, Moyudan, Seyegan, dan Tempel termasuk ke dalam kelompok yang memberikan kontribusi rendah bagi 
PDRB kabupaten dan juga memiliki pertumbuhan ekonomi yang rendah.

Prasetiyo, Yudo Agus (2004), melakukan penelitian tentang Analisis Penetapan Strategi Perusahaan Guna Meningkatkan Daya Saing Pada PT Cipta Niaga Dengan Analisis SWOT, BCG Matrix, dan analisis lainnya. Hasil penelitian menunjukkan bahwa dalam kondisi persaingan bisnis yang sangat ketat seperti saat ini dibutuhkan informasi yang cepat dan metode analisis yang akurat. Pada persaingan yang semakin ketat karena keadaan pasar yang terbuka dan kondisi ekonomi yang belum stabil diperlukan strategi yang tepat untuk melanjutkan kelangsungan perusahaan untuk meningkatkan daya saing perusahaan PT Cipta Niaga Palembang yang bergerak pada bidang distribusi barang-barang kebutuhan rumah tangga (customer good).Sebagai kompetitor, PT A bergerak dalam bidang yang sama. Tujuan yang ingin dicapai pada penelitian ini adalah untuk menganalisis tingkat pemasaran dan menentukan strategi yang tepat untuk meningkatkan daya saing terhadap perusahaan yang sejenis yang ada pada pasar domestik. Perumusan strategi perusahaan dilakukan dengan menggunakan analisis SWOT, BCG Matrix, dan analsis lainnya. Penerapan metode tersebut dilakukan dengan evaluasi dan analisis terhadap keadaan intern dan ekstern perusahaan yang meliputi peluang, ancaman, kekuatan, kelemahan, kekuatan bisnis, daya tarik industri, dan faktor-faktor yang mempengaruhi perkembangan kedua perusahaan. Berdasarkan hasil evaluasi diperoleh alternatif strategi untuk masing-masing perusahaan, yaitu untuk PT Cipta Niaga adalah strategi market growth dan untuk PT A adalah strategi market development.
Dalam rangka merangsang pertumbuhan ekonomi dan meningkatkan kualitas hidup masyarakat, Pemerintah Kabupaten Sleman menerapkan pemasaran wilayah (marketing place) bagi fokus potensi ETI (Education, Tourism dan Investment). Strategi ini diperlukan sebagai value indicator yang akan memberikan pesan yang kuat kepada stakeholder. Kabupaten Sleman sebagai daerah tujuan pendidikan mempunyai atmosfer intelektual yang sangat kuat. Di Kabupaten Sleman terdapat 37 perguruan tinggi yang terdiri dari 5 Perguruan Tinggi Negeri (PTN) dan 32 Perguruan Tinggi Swasta (PTS), dengan mahasiswa lebih dari 150.000 orang, terkonsentrasi di Kecamatan Depok (4 PTN dan 19 PTS).

Perguruan tinggi tersebut tumbuh dengan mahasiswa berasal dari berbagai benua untuk mempelajari berbagai disiplin ilmu dalam berbagai tingkatan strata. Sebagai barometer pendidikan, Kabupaten Sleman mempunyai fasilitas dan infrastruktur yang lengkap dan modern. Sistem pendidikan dikembangkan dengan konsep link and match yang sesuai dengan kebutuhan masyarakat dan pasar kerja. Secara umum, perguruan tinggi di Kabupatan Sleman berorientasi pada pembentukan intellectual skill, communications skill, dan interpersonal skill untuk menghasilkan sumber daya manusia (SDM) yang memiliki etos kerja profesional yang dibutuhkan di era bisnis global. Untuk itu, Kabupaten Sleman menyediakan zona dan fasilitas pembangunan kampus yang dapat mendukung proses belajar mengajar seperti student housing, auditorium, fasilitas olah raga indoor/outdoor, jaringan infrastuktur, dan utilitas. Sistem informasi juga diciptakan untuk membangun networking antara kampus dengan customer. 
PTS di Kabupaten Sleman memiliki karakteristik berbeda satu sama lain. Perbedaan karakteristik ini disebabkan perbedaan sumberdaya yang dimiliki, baik sumberdaya fisik, sumber daya non fisik (sumberdaya manusia), ataupun sumber modal. Sumberdaya yang dimiliki oleh suatu PTS menentukan jenis produk/kegiatan yang difokuskan untuk dikembangkan. Pemilihan jenis produk/kegiatan PTS yang akan dikembangkan didasarkan pada keunggulan yang dimiliki oleh PTS tersebut. Keunggulan dapat diperoleh dari sumberdaya spesifik yang dimiliki. Jika suatu PTS memiliki sumberdaya yang spesifik dan tidak dimiliki oleh PTS lain, baik jenis, mutu, maupun jumlahnya menunjukkan bahwa PTS tersebut memiliki keunggulan memproduksi produk yang menggunakan input utama sumberdaya tersebut. Pemilihan terhadap produk yang memiliki keunggulan untuk dikembangkan oleh PTS, berarti PTS tersebut melakukan spesialisasi. Spesialisasi dalam kegiatan sektor sangat penting, mengingat sumberdaya yang dimiliki oleh PTS sangat terbatas. Dengan melakukan spesialisasi diharapkan penggunaan sumberdaya yang dimiliki PTS tidak mubajir.

Salah satu cara untuk mengetahui suatu PTS memiliki keunggulan di antara PTS-PTS yang lain adalah dengan menggunakan matriks pertumbuhan-pangsa pasar (growthshare matrix - GS Matrix). GS Matrix atau Boston Consultant Group Matrix /BCG Matrix memiliki empat kuadran yang dipisahkan oleh dua sumbu, yaitu sumbu vertikal dan sumbu horisontal. Sumbu vertikal menunjukkan kontribusi PTS terhadap PTS keseluruhan di Kabupaten Sleman dan sumbu horisontal menunjukkan laju pertumbuhan PTS. Kontribusi suatu PTS diukur dari kontribusi persentase jumlah mahasiswa PTS tersebut terhadap jumlah mahasiswa PTS keseluruhan di Kabupaten Sleman. Sedangkan laju pertumbuhan PTS diukur dari persentase perubahan jumlah mahasiswa PTS tersebut dari tahun ke tahun.

Lingkaran-lingkaran pada GS Matrix menunjukkan kontribusi dan laju pertumbu-

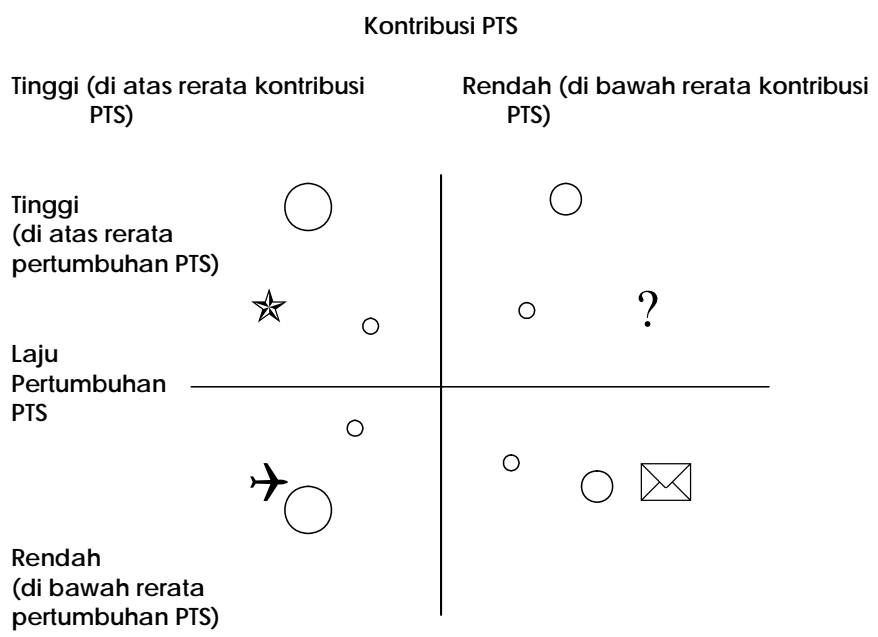

Gambar 1. Matriks BCG PTS di Kabupaten Sleman 
han PTS. Masing-masing PTS dikelompokkan berdasarkan tinggi rendahnya kontribusi dan pertumbuhan masing-masing PTS. PTS yang memiliki kontribusi jumlah mahasiswa di atas kontribusi jumlah mahasiswa rerata dikelompokkan ke dalam PTS yang memiliki kontribusi tinggi, dan sebaliknya. Demikian juga dengan pengelompokkan PTS berdasarkan pertumbuhan jumlah mahasiswa. PTS yang memiliki pertumbuhan jumlah mahasiswa di atas rerata pertumbuhan jumah mahasiswa semua PTS dikelompokkan ke dalam kelompok PTS yang memiliki pertumbuhan tinggi, dan sebaliknya.

PTS yang dipilih sebagai sampel dalam penelitian ini adakah empat PTS besar berdasarkan jumlah mahasiswa dan berlokasi yang saling berdekatan di Kecamatan Depok, yaitu Universitas Islam Indonesia (UII), Universitas Atma Jaya Yogyakarta (UAJY), Universitas Pembangunan Nasional Veteran Yogyakarta (UPNVY), dan Sekolah Tinggi Ilmu Ekonomi Yayasan Keluarga Pahlawan Negara Yogyakarta (STIE YKPN). Oleh karena keempat PTS tersebut memiliki Pro- gram Strata 1 (S-1) Fakultas Ekonomi dengan program studi Akuntansi, Manajemen, dan Ekonomi Pembangunan sehingga dapat dibandingkan antara keempat PTS tersebut, maka sebagai obyek penelitian adalah jumlah mahasiswa baru S-1 program studi Akuntansi, Manajemen, dan Ekonomi Pembangunan. Berdasarkan data yang diakses dari Departemen Pendidikan Nasional Direktorat Jenderal Pendidikan Tinggi diperoleh data yang tersaji dalam Tabel 6 .

Berdasarkan Tabel 6, nampak masingmasing program studi di PTS tersebut memiliki perkembangan jumlah mahasiswa baru selama tahun 2002-2007 yang berbeda. Perbedaan ini disebabkan masing-masing program studi (PS) di PTS tersebut memiliki karakteristik yang berbeda satu sama lain karena perbedaan sumberdaya yang dimiliki, baik sumberdaya fisik, sumber daya non fisik (sumberdaya manusia), ataupun sumber modal. Berdasarkan uraian tersebut, peneliti menyimpulkan bahwa:

Tabel 6. Jumlah Mahasiswa Baru Empat PTS di Kabupaten Sleman, Tahun 2002-2007

\begin{tabular}{|c|c|c|c|c|c|c|}
\hline Program Studi (PS) & 2002 & 2003 & 2004 & 2005 & 2006 & 2007 \\
\hline \multicolumn{7}{|c|}{ UII } \\
\hline S-1 Akuntansi & 444 & 413 & 452 & 447 & 524 & 497 \\
\hline S-1 Manajemen & 502 & 509 & 486 & 487 & 399 & 368 \\
\hline S-1 Ekonomi Pemb. & 122 & 125 & 105 & 77 & 39 & 71 \\
\hline \multicolumn{7}{|c|}{ UAJY } \\
\hline S-1 Akuntansi & 314 & 283 & 272 & 276 & 283 & 231 \\
\hline S-1 Manajemen & 306 & 300 & 296 & 272 & 274 & 238 \\
\hline S-1 Ekonomi Pemb. & 57 & 142 & 52 & 27 & 30 & 31 \\
\hline \multicolumn{7}{|c|}{ UPNVY } \\
\hline S-1 Akuntansi & 363 & 413 & 320 & 320 & 278 & - \\
\hline S-1 Manajemen & 845 & 769 & 541 & 386 & 371 & - \\
\hline S-1 Ekonomi Pemb. & 239 & 139 & 57 & 47 & 69 & - \\
\hline \multicolumn{7}{|c|}{ STIEYKPN } \\
\hline S-1 Akuntansi & 594 & 509 & 566 & 500 & 295 & 379 \\
\hline S-1 Manajemen & 579 & 418 & 337 & 275 & 127 & 168 \\
\hline S-1 Ekonomi Pemb. & 23 & 15 & 22 & 6 & 5 & 11 \\
\hline
\end{tabular}

Sumber: http://www.evaluasi.or.id. 
H1: ada perbedaan rata-rata kontribusi jumlah mahasiswa baru pada program studi Akuntansi di UII, UAJY, UPNVY, dan STIE YKPN.

H2: ada perbedaan rata-rata kontribusi jumlah mahasiswa baru pada program studi Manajemen di UII, UAJY, UPNVY, dan STIE YKPN.

H3: ada perbedaan rata-rata kontribusi jumlah mahasiswa baru pada program studi Ekonomi Pembangunan di UII, UAJY, UPNVY, dan STIE YKPN.

H4: ada perbedaan rata-rata pertumbuhan jumlah mahasiswa baru pada program studi Akuntansi di UII, UAJY, UPNVY, dan STIE YKPN.

H5: ada perbedaan rata-rata pertumbuhan jumlah mahasiswa baru pada program studi Manajemen di UII, UAJY, UPNVY, dan STIE YKPN.

H6: ada perbedaan rata-rata pertumbuhan jumlah mahasiswa baru pada program studi Ekonomi Pembangunan di UII, UAJY, UPNVY, dan STIE YKPN.

Pengujian hipotesis dilakukan menggunakan model anova satu arah. Model arah ini digunakan untuk pengujian perbedaan antara $k$ rata-rata sampel apabila subyek-subyek penelitian ditentukan secara random pada setiap grup atau kelompok perlakuan yang ditentukan (Subiyakto, 2004: 41). Dalam penelitian ini $\alpha$ ditetapkan sebesar 5 persen.

\section{HASIL PENELITIAN DAN PEMBAHASAN}

Berdasarkan data jumlah mahasiswa baru selama tahun 2002-2007 pada masingmasing program studi di PTS tersebut (Tabel 6), maka dapat dihitung kontribusi jumlah mahasiswa baru selama tahun 2002-2007 pada masing-masing program studi di PTS tersebut yang hasilnya ditunjukkan pada Tabel 7.

Berdasarkan data jumlah mahasiswa baru selama tahun 2002-2007 pada masing-

Tabel 7. Kontribusi Jumlah Mahasiswa Baru Empat PTS di Kabupaten Sleman, Tahun 2002-2007

\begin{tabular}{|c|c|c|c|c|c|c|c|}
\hline Program Studi (PS) & 2002 & 2003 & 2004 & 2005 & 2006 & 2007 & rata-rata \\
\hline & & & UII & & & & \\
\hline S-1 Akuntansi & $25.89 \%$ & $25.53 \%$ & $28.07 \%$ & $28.97 \%$ & $37.97 \%$ & $44.90 \%$ & $31.89 \%$ \\
\hline$S-1 N$ & & & $29.28 \%$ & & & & $20 \%$ \\
\hline S-1 Ekonomi Pemb. & $27.66 \%$ & $29.69 \%$ & $\begin{array}{l}44.49 \% \\
\text { UAJY }\end{array}$ & $49.04 \%$ & $27.27 \%$ & & $40.17 \%$ \\
\hline S-1 Akuntansi & $18.31 \%$ & & & & & & $18.66 \%$ \\
\hline S-1 $N$ & & & & & & & \\
\hline S-1 Ekonomi Pemb. & & & $\begin{array}{l}22.03 \% \\
\text { UPNVY }\end{array}$ & & $20.98 \%$ & $27.43 \%$ & $22.38 \%$ \\
\hline & & & $19.88 \%$ & & & & $17.91 \%$ \\
\hline & 3 & & & & & & $27.97 \%$ \\
\hline S-1 Ekonomi Pemb. & $54.20 \%$ & $33.02 \%$ & $\begin{array}{c}24.15 \% \\
\text { STIE YKPN }\end{array}$ & $29.94 \%$ & $48.25 \%$ & $0.00 \%$ & $31.59 \%$ \\
\hline S-1 AK & 1610 & $31.46 \%$ & $35.16 \%$ & $32.40 \%$ & & & $31.54 \%$ \\
\hline & 2 & 20.94 & & & & $21.71 \%$ & $19.85 \%$ \\
\hline S-1 Ekonomi Pemb. & $5.22 \%$ & $3.56 \%$ & $9.32 \%$ & $3.82 \%$ & $3.50 \%$ & $9.73 \%$ & $5.86 \%$ \\
\hline
\end{tabular}

Sumber: Diolah dari Tabel 6. 
masing program studi di PTS tersebut (Tabel 6), maka dapat dihitung pertumbuhan jumlah mahasiswa baru selama tahun 2002-2007 pada masing-masing program studi di PTS tersebut yang hasilnya ditunjukkan pada Tabel 8.
Berdasarkan data pada Tabel 7 dan Tabel 8, maka dapat disarikan nilai kualitatif kontribusi dan pertumbuhan jumlah mahasiswa empat PTS di Kabupaten Sleman seperti yang nampak pada Tabel 9.

Berdasarkan Tabel 9, maka dapat di-

Tabel 8. Pertumbuhan Jumlah Mahasiswa Baru Empat PTS di Kabupaten Sleman, Tahun 2002-2007

\begin{tabular}{lrrrrrr}
\hline Program Studi (PS) & \multirow{2}{*}{ 2003 } & \multirow{2}{*}{$\mathbf{2 0 0 4}$} & $\mathbf{2 0 0 5}$ & $\mathbf{2 0 0 6}$ & $\mathbf{2 0 0 7}$ & rata-rata \\
\hline S-1 Akuntansi & $-6.98 \%$ & $9.44 \%$ & $-1.11 \%$ & $17.23 \%$ & $-5.15 \%$ & $2.69 \%$ \\
S-1 Manajemen & $1.39 \%$ & $-4.52 \%$ & $0.21 \%$ & $-18.07 \%$ & $-7.77 \%$ & $-5.75 \%$ \\
S-1 Ekonomi Pemb. & $2.46 \%$ & $-16.00 \%$ & $-26.67 \%$ & $-49.35 \%$ & $82.05 \%$ & $-1.50 \%$ \\
\multicolumn{7}{c}{ UAJY } \\
S-1 Akuntansi & $-9.87 \%$ & $-3.89 \%$ & $1.47 \%$ & $2.54 \%$ & $-18.37 \%$ & $-5.63 \%$ \\
S-1 Manajemen & $-1.96 \%$ & $-1.33 \%$ & $-8.11 \%$ & $0.74 \%$ & $-13.14 \%$ & $-4.76 \%$ \\
S-1 Ekonomi Pemb. & $149.12 \%$ & $-63.38 \%$ & $-48.08 \%$ & $11.11 \%$ & $3.33 \%$ & $10.42 \%$ \\
& \multicolumn{7}{c}{ UPNVY } \\
S-1 Akuntansi & $13.77 \%$ & $-22.52 \%$ & $0.00 \%$ & $-13.13 \%$ & - & $-5.47 \%$ \\
S-1 Manajemen & $-8.99 \%$ & $-29.65 \%$ & $-28.65 \%$ & $-3.89 \%$ & - & $-17.79 \%$ \\
S-1 Ekonomi Pemb. & $-41.84 \%$ & $-58.99 \%$ & $-17.54 \%$ & $46.81 \%$ & - & $-17.89 \%$ \\
& \multicolumn{7}{c}{ STIE YKPN } \\
S-1 Akuntansi & $-14.31 \%$ & $11.20 \%$ & $-11.66 \%$ & $-41.00 \%$ & $28.47 \%$ & $-5.46 \%$ \\
S-1 Manajemen & $-27.81 \%$ & $-19.38 \%$ & $-18.40 \%$ & $-53.82 \%$ & $32.28 \%$ & $-17.42 \%$ \\
S-1 Ekonomi Pemb. & $-34.78 \%$ & $46.67 \%$ & $-72.73 \%$ & $-16.67 \%$ & $120.00 \%$ & $8.50 \%$ \\
\hline
\end{tabular}

Sumber: Diolah dari Tabel 6.

Tabel 9. Pertumbuhan dan Kontribusi Empat PTS di Kabupaten Sleman, 2002-2007

\begin{tabular}{lcc}
\hline \multicolumn{1}{c}{ Program Studi } & Pertumbuhan & Kontribusi \\
\hline S-1 Akuntansi & UII & \\
S-1 Manajemen & tinggi & Tinggi \\
S-1 Ekonomi Pemb. & tinggi & Tinggi \\
& rendah & Tinggi \\
S-1 Akuntansi & UAJY & \\
S-1 Manajemen & rendah & Rendah \\
S-1 Ekonomi Pemb. & tinggi & Rendah \\
& tinggi & Rendah \\
S-1 Akuntansi & UPNVY & \\
S-1 Manajemen & rendah & Rendah \\
S-1 Ekonomi Pemb. & rendah & Tinggi \\
& rendah & Tinggi \\
S-1 Akuntansi & STIE YKPN & \\
S-1 Manajemen & rendah & Tinggi \\
S-1 Ekonomi Pemb. & rendah & rendah \\
\hline
\end{tabular}

Sumber: Diolah dari Tabel 7 dan Tabel 8. 
gambarkan posisi masing-masing Program Studi Akuntansi, Manajemen, dan Ekonomi Pembangunan di UII, UAJY, UPNVY, dan STIE YKPN dalam Matriks BCG seperti yang nampak pada Gambar 2.

Hasil pengujian hipotesis untuk mengetahui signifikan tidaknya perbedaan rata-rata kontribusi dan pertumbuhan jumlah mahasiswa baru pada masing-masing program studi Akuntansi, Manajemen, dan Ekonomi Pembangunan di UII, UAJY, UPNVY, dan STIE YKPN dengan Anova satu arah pada tingkat signifikansi sebesar 0,05 . (Tabel 9)

Berdasarkan Tabel 10 nampak nilai $\mathrm{F}$ test $\mathrm{H} 1$ adalah 8,41 dengan nilai $\mathrm{P}$ value = 0,0008 yang berarti signifikan pada $\alpha=0,05$. Ini berarti hipotesis yang menyatakan bahwa ada perbedaan rata-rata kontribusi jumlah mahasiswa baru pada program studi Akuntansi di UII, UAJY, UPNVY, dan STIE YKPN diterima. Nilai $\mathrm{F}$ test $\mathrm{H} 2$ adalah 2,59 dengan nilai $\mathrm{P}$ value $=0,0816$ yang berarti tidak signifikan pada $\alpha=0,05$.

Ini berarti hipotesis yang menyatakan bahwa ada perbedaan rata-rata kontribusi jumlah mahasiswa baru pada program studi Manajemen di UII, UAJY, UPNVY, dan STIE YKPN ditolak. Nilai $\mathrm{F}$ test $\mathrm{H} 3$ adalah 8,07 dengan nilai $\mathrm{P}$ value $=0,0010$ yang berarti signifikan pada $\alpha=0,05$. Ini berarti hipotesis yang menyatakan bahwa ada perbedaan rata-rata kontribusi jumlah mahasiswa baru pada program studi Ekonomi Pembangunan di UII, UAJY, UPNVY, dan STIE YKPN diterima.

Nilai $\mathrm{F}$ test $\mathrm{H} 4$ adalah 0,29 dengan nilai $\mathrm{P}$ value $=0,8313$ yang berarti tidak signifikan pada $\alpha=0,05$. Ini berarti hipotesis yang menyatakan bahwa ada perbedaan rata-rata pertumbuhan jumlah mahasiswa baru pada program studi Akuntansi di UII, UAJY, UPNVY, dan STIE YKPN ditolak. Nilai F test $\mathrm{H} 5$ adalah 0,62 dengan nilai $\mathrm{P}$ value = 0,6135 yang berarti tidak signifikan pada $\alpha=$ 0,05 . Ini berarti hipotesis yang menyatakan bahwa ada perbedaan rata-rata pertumbuhan jumlah mahasiswa baru pada program studi Manajemen di UII, UAJY, UPNVY, dan STIE YKPN ditolak. Nilai F test H6 adalah 0,15 dengan nilai $\mathrm{P}$ value $=0,9274$ yang berarti tidak signifikan pada $\alpha=0,05$. Ini berarti hipotesis yang menyatakan bahwa ada perbedaan rata-rata pertumbuhan jumlah mahasiswa baru pada program studi Ekonomi Pembangunan di UII, UAJY, UPNVY, dan STIE YKPN ditolak

Berdasarkan Gambar 2, PTS yang terletak pada kuadran satu (bergambar ?) menunjukkan bahwa PTS tersebut mempunyai

Tabel 10. Hasil Pengujian Hipotesis dengan Anova

\begin{tabular}{cccl}
\hline Hipotesis & F test & P value & \multicolumn{1}{c}{ Pengujian } \\
\hline H1 & 8,41 & 0,0008 & signifikan \\
H2 & 2,59 & 0,0816 & tidak signifikan \\
H3 & 8,07 & 0,0010 & signifikan \\
H4 & 0,29 & 0,8313 & tidak signifikan \\
H5 & 0,62 & 0,6135 & tidak signifikan \\
H6 & 0,15 & 0,9274 & tidak signifikan \\
\hline
\end{tabular}

Sumber: Tabel 7 dan 8. Data diolah. 
kontribusi rendah, tetapi laju pertumbuhan tinggi. PTS yang terletak pada kuadran satu ini memiliki peluang pasar yang besar. Hal ini ditunjukkan oleh pertumbuhan yang tinggi di PTS ini. Dengan demikian, PS Manajemen dan PS Ekonomi Pembangunan UAJY, serta PS Ekonomi Pembangunan STIE YKPN yang terletak pada kuadran satu ini berpotensi untuk dikembangkan. Strategi pengembangan PTS ini adalah dengan menambah modal.

PTS yang terletak pada kuadran dua (bergambar *) menunjukkan bahwa PTS tersebut memiliki laju pertumbuhan tinggi dan kontribusi tinggi. Dengan demikian, PTS tersebut merupakan PTS yang memiliki potensi berkembang, karena PTS tersebut berada pada pasar yang memiliki laju pertumbuhan tinggi. Selain itu, PTS itu juga memberikan kontribusi tinggi. Strategi pengembangan PS Akuntansi dan PS Manajemen UII yang berada pada kuadran dua adalah memperbesar permodalan untuk melayani permintaan dari laju pertumbuhan pasar yang tinggi dan berusaha mempertahankan kontribusi yang telah dimiliki.

PTS yang terletak pada kuadran tiga (bergambar $\uparrow$ ) merupakan PTS yang berhasil, karena PTS tersebut memiliki kontribusi yang tinggi, walaupun laju pertumbuhan relatif rendah. PTS yang terletak pada kuadran tiga tidak memerlukan investasi besar. Hal ini disebabkan laju pertumbuhan pasar juga relatif rendah. Jika diinginkan memperbesar investasi PTS tersebut, pengelola PS Ekonomi Pembangunan UII, PS Manajemen dan PS Ekonomi Pembangunan UPNVY, serta PS Akuntansi STIE YKPN harus berusaha menciptakan pasar atau mencari pasar baru bagi produk-produk PTS tersebut.
PTS yang terletak pada kuadran empat (bergambar $\varangle$ ) dapat diartikan bahwa PTS tersebut memiliki potensi yang rendah, karena PTS tersebut memiliki pertumbuhan pasar rendah dan memberikan kontribusi yang rendah pula. PTS tersebut memiliki tingkat keunggulan yang relatif rendah, sehingga PTS tersebut hanya mampu menyerap sebagian kecil permintaan pasar. Investasi pada PTS tersebut tidak dapat memberikan prospek yang baik, karena laju pertumbuhan PTS tersebut juga rendah. Strategi pengembangan PS Akuntansi UAJY, PS Akuntansi UPNVY, dan PS Manajemen STIE YKPN yang berada pada kuadran empat adalah dengan melakukan diversifikasi produk untuk menciptakan pasar baru atau mencari pasar di luar pasar yang sudah ada.

Berdasarkan Tabel 10, nampak H1 dan H3 diterima sedang H2 ditolak secara signifikan pada $\alpha=5 \%$. Perbedaan rata-rata kontribusi jumlah mahasiswa baru pada program studi Akuntansi di UII, UAJY, UPNVY, dan STIE YKPN terjadi karena perbedaan sumberdaya yang dimiliki, baik sumberdaya fisik, sumber daya non fisik (sumberdaya manusia), ataupun sumber modal. Sumberdaya yang dimiliki oleh suatu PS menentukan jenis produk/kegiatan yang difokuskan untuk dikembangkan. Sebagai contoh, perbedaan pada aspek kuantitas dan kualitas dosen PS Akuntansi di antara keempat PTS tersebut mengakibatkan perbedaan dalam penawaran jenis produk pengembangan, yaitu Program Magister Akuntansi (MAKSI) dan Program Pendidikan Profesi Akuntansi (PPA) yang hanya ditawarkan oleh PS Akuntansi STIE YKPN. Demikian juga dengan perbedaan rata-rata kontribusi jumlah mahasiswa baru pada program studi Ekonomi Pembangunan di UII, UAJY, UPNVY, dan STIE YKPN 
terjadi karena perbedaan sumberdaya yang dimiliki. Sebagai contoh, perbedaan dalam penawaran jenis produk pengembangan, yaitu Program Magister Ekonomi Pembangunan (MEP) yang hanya ditawarkan oleh PS Ekonomi Pembangunan UPNVY dan Program Doktor Ilmu Ekonomi yang hanya ditawarkan oleh PS Ekonomi Pembangunan UII. Tidak adanya perbedaan rata-rata kontribusi jumlah mahasiswa baru pada program studi Manajemen di UII, UAJY, UPNVY, dan STIE YKPN terjadi karena keempat PTS tersebut tidak memiliki perbedaan dalam penawaran jenis produk pengembangan, yaitu Program Magister Manajemen (MM) karena keempat PTS semuanya menawarkan Program MM.

Berdasarkan Tabel 10, nampak H4, H5, dan H6 ditolak secara signifikan pada $\alpha=$ $5 \%$. Tidak adanya perbedaan rata-rata pertumbuhan jumlah mahasiswa baru pada program studi Akuntansi, Manajemen, dan Ekonomi Pembangunan di UII, UAJY, UPNVY, dan STIE YKPN karena sebagai PTS yang besar di Kabupaten Sleman, keempat PTS tersebut memiliki keterbatasan dalam memperoleh input (calon mahasiswa) yang relatif sebagian besar berasal dari luar Propinsi DIY. Dampak otonomi daerah, telah menimbulkan penurunan terhadap minat calon mahasiswa untuk melanjutkan kuliah di DIY pada umumnya dan Kabupaten Sleman pada khususnya karena di berbagai kota/kabupaten di luar Propinsi DIY telah tumbuh dan berkembang berbagai PT. Oleh karena itu, agar PTS di Kabupaten Sleman mampu tumbuh dan berkembang maka masing-masing PTS harus memilih strategi pengembangan PTS yang spesifik berbeda bahkan untuk masing-masing PS di masingmasing PTS.

\section{KESIMPULAN}

Dampak otonomi daerah telah menimbulkan penurunan terhadap minat calon mahasiswa untuk melanjutkan kuliah di DIY pada umumnya dan Kabupaten Sleman pada khususnya karena di berbagai kota/kabupaten di luar Propinsi DIY telah tumbuh dan berkembang berbagai PT. Oleh karena itu, agar PTS di Kabupaten Sleman mampu tumbuh dan berkembang maka masing-masing PTS harus memilih strategi pengembangan PTS yang spesifik berbeda bahkan untuk masing-masing PS di masing-masing PTS.

Perbedaan rata-rata kontribusi jumlah mahasiswa baru pada PS Akuntansi dan Ekonomi Pembangunan di UII, UAJY, UPNVY, dan STIE YKPN terjadi karena perbedaan sumberdaya yang dimiliki, baik sumberdaya fisik, sumber daya non fisik (sumberdaya manusia), ataupun sumber modal. Sumberdaya yang dimiliki oleh suatu PS menentukan jenis produk/kegiatan yang difokuskan untuk dikembangkan. Tidak adanya perbedaan rata-rata pertumbuhan jumlah mahasiswa baru pada PS Akuntansi, Manajemen, dan Ekonomi Pembangunan di UII, UAJY, UPNVY, dan STIE YKPN karena sebagai PTS yang besar di Kabupaten Sleman, keempat PTS tersebut memiliki keterbatasan dalam memperoleh input (calon mahasiswa) yang relatif sebagian besar berasal dari luar Propinsi DIY.

Saran-saran yang diajukan dari hasil penelitian ini sebagai berikut:

Penelitian ini menggunakan sampel PS Akuntansi, Manajemen, dan Ekonomi Pembangunan 4 PTS di Kabupaten Sleman, Propinsi DIY. Mempertimbangkan di Kabupaten Sleman terdapat 37 perguruan tinggi yang terdiri dari 5 Perguruan Tinggi Negeri 
(PTN) dan 32 Perguruan Tinggi Swasta (PTS), dengan mahasiswa lebih dari 150.000 orang, terkonsentrasi di Kecamatan Depok sebanyak 4 PTN dan 19 PTS, maka dalam penelitian berikutnya hendaknya memperbanyak jumlah PTS dengan memasukkan PTS yang dianggap kecil dalam jumlah mahasiswanya. Penambahan obyek penelitian sangat penting untuk mengetahui dampak otonomi daerah terhadap strategi pengembangan PTS besar dan kecil di Kabupaten Sleman.

\section{DAFTAR PUSTAKA}

Algifari dan Rudy Badrudin. Desember 2003, Strategi Pengembangan Kecamatan Menggunakan Growth-Share Boston Consulting Group (Bcg) Matrix (Studi Kasus di Kabupaten Sleman, DIY. Jurnal Akuntansi \& Manajemen (JAM). Vol. XVII, No. 3: 203-213.

Andriani, Lis, HR. Januari 2001. Analisis Strategi Perguruan Tinggi: Telaah Faktor Eksternal dan Internal Sebagai Dasar Penentuan Posisi Keunggulan Kompetitif dan Pemilihan Strategi: Kasus FE Jurusan Manajemen pada 9 Perguruan Tinggi Swasta di Kota Surabaya. Jurnal Ekonomi. Fakultas Ekonomi Universitas Airlangga. Diakses dari http://www.unair.ac.id.

Bounds, Greg, et. al. 1994. Beyond Total Quality Management: Toward the Emerging Paradigm. Singapore: McGraw-Hill.

Badan Pusat Statistik. 2002. Sleman dalam Angka. Sleman: BPS.

http://web.ugm.ac.id/um-ugm/um-ugm-php.

http://www.evaluasi.or.id.
Kate, Ashcroft. (1995). The Lecturer's Guide to Quality and Standards in Colleges and Universities. London: The Falmer Press.

Kedaulatan Rakyat, 2004, 27-29 April. Seleksi terhadap Mahasiswa Baru Berkaitan dengan Tes Narkoba.

Kompas, 2004, 12 April. Biaya Pendidikan di Yogyakarta: Laporan Hasil Penelitian Bank Indonesia (BI) Yogyakarta, Tahun 2000-2002. Hlm. A

Kompas, 2003, 22 Juni. Survei Biaya Pendidikan di Perguruan Tinggi di Berbagai Kota. hlm 32.

Kopertis Wilayah V. Laporan Jumlah Mahasiswa Tahun 2001-2003. Yogyakarta: Kopertis.

M. Zainuddin dan Susy Puspitasari (2001). Strategi Peningkatan Kualitas Pendidikan Tinggi. Bahan Pelatihan Pekerti PAU. Jakarta: Dirjen Dikti.

Maisyaroh, Arifa dan Debora Anggraini (2005). Kompetisi dan Strategi dalam Membangun Perguruan Tinggi pada era Globalisasi. Jurnal Manajemen STIEMCE.

Prasetiyo, Yudo Agus (2004). Analisis Penetapan Strategi Perusahaan Guna Meningkatkan Daya Saing Pada PT Cipta Niaga dengan Analisis SWOT. Jurnal Kompilasi. STT Musi Palembang. Diakses dari http//:www.musi.ac.id

Supriyono, RA. (1998). Manajemen Strategi dan Kebijaksanaan Bisnis. Ed. 2. Yogyakarta: BPFE UGM. 